\title{
ANALYSIS OF BU HARTIN RESTAURANT COMPETITIVE STRATEGY IN THE DEVELOPMENT OF CULINARY IN WATES KULON PROGO
}

\author{
T. Prasetyo Hadi Atmoko(1), Heni Widyaningsih ${ }^{(2)}$ \\ (1) (2) Hospitality Study Program, Akademi Pariwisata Yogyakarta \\ prasplg@gmail.com, heni.widya08@akparyo.ac.id
}

Submitted: 10 March 2020 Revised:2 April 2020

Accepted :6 April 2020

\begin{abstract}
ABSTRAK
Tujuan dari penelitian ini adalah untuk mengetahui kekuatan dan kelemahan, mengetahui peluang dan ancaman, mengetahui bauran pemasaran dan mengetahui strategi bersaing restoran $\mathrm{Bu}$ Hartin. Penelitian ini adalah penelitian kualitatif dengan kunci informan adalah pemilik restoran Bu Hartin dengan Teknik Analisis SWOT. Berdasarkan Analisis SWOT, dapat disimpulkan bahwa faktor kekuatan restoran Bu Hartin memiliki skor 2,36 dan faktor kelemahan memiliki skor 0,08. Faktor peluang memiliki skor 2,99 dan faktor ancaman memiliki skor 0,07. Bauran pemasaran restoran Bu Hartin mencakup tujuh elemen, seperti produk, harga, tempat, promosi, peserta, bukti fisik, dan proses. Hasil dari produk Bu Hartin restaurant adalah menu spesial untuk ayam kampung, iga bakar, dan sup iga. Harga makanan di restoran $\mathrm{Bu}$ Hartin terjangkau untuk siswa dan bahkan untuk karyawan kantor. Lokasi restoran $\mathrm{Bu}$ Hartin sangat strategis, dekat dengan pusat kota. Promosi untuk restoran $\mathrm{Bu}$ Hartin dilakukan melalui media sosial. Restoran $\mathrm{Bu}$ Hartin memiliki karyawan yang berpengalaman di bidangnya sehingga layanan kepada pelanggan sangat baik. Fasilitas fisik yang dimiliki oleh restoran $\mathrm{Bu}$ Hartin yaitu gazebo yang dapat digunakan sebagai tempat istirahat bagi pelanggan. Proses memasak di restoran Bu Hartin menggunakan bumbu spesial dan lezat sehingga cocok untuk semua tingkat pelanggan. Proses memasaknya cukup cepat, sekitar 10 menit sehingga pelanggan tidak menunggu lama. Berdasarkan diagram SWOT, restoran $\mathrm{Bu}$ Hartin berada pada strategi SO dengan meningkatkan promosi melalui media sosial dan memperluas cabang.
\end{abstract}

Kata Kunci: Pengembangan Kuliner, Restoran, Strategi Kompetitif

\section{ABSTRACT}

The purpose of this research is to find out the strengths and weaknesses, know the opportunities and threats, know the marketing mix and to know the competitive strategy of Bu Hartin restaurant. This research is qualitative research with the key of an informant is the owner of Bu Hartin restaurant with SWOT Analysis Technique. Based on SWOT Analysis, it can be concluded that the strength factor of Bu Hartin restaurant has a score of 2.36 and the weaknesses factor has a score of 0.08. The opportunity factor has a score of 2.99 and the threats factor has a score of 0.07. The marketing mix of Bu Hartin restaurant includes seven elements, such as product, price, place, promotion, participants, physical evidence, and process. The result of the product of Bu Hartin restaurant is a special menu for free-range chicken, grilled ribs, and ribs soup. The food prices at Bu Hartin restaurant are affordable for students and even for office employees. Location Bu Hartin restaurant is very strategic,

JITHOR Vol.3, No.1, April 2020 - eISSN : 2654-4687 pISSN : 2654-3894 - 67 
T. Prasetyo Hadi Atmoko and Heni Widyaningsih: Analysis of Bu Hartin Restaurant Competitive Strategy in the Development of Culinary in Wates Kulon Progo"

close to the city center. Promotion for Bu Hartin restaurant is conducted through social media. Bu Hartin restaurant has employees who are experienced in their fields so that the services to the customers are very well. Physical facilities owned by Bu Hartin restaurant that is a gazebo that can be used as a resting place for the customers. The cooking process at Bu Hartin restaurant applies special and delicious spices so that it is suitable for all customers' levels. The cooking process is quite fast, approximately 10 minutes so that the customers do not wait for a long period. Based on the SWOT diagram, Bu Hartin restaurant is on the SO strategy by increasing promotion through social media and expanding branches.

\section{Keywords: Competitive Strategy, Culinary Development, Restaurant}

\section{INTRODUCTION}

Indonesian citizen are getting busier with their respective activities inducing the development of restaurants growing rapidly. Outside house activities cause people necessary to demand food and beverage services. In addition, the number of tourist attractions in Indonesia has an impact on the development of hotel business, restaurants, transportation, and travel agencies which are tourism industry elements that attract a lot of consumer interest (Atmoko, 2018). It leads to business players to expand restaurants as businesses. Competitively business competition in nowadays, customer satisfaction becomes something that must be concerned. The quality of services provided must be appropriate because the expectations of the customers are always changing. The quality of service is also a level of ability to provide services as a competitive strategy to meet customers' needs (Palupi, 2018).

As a service industry, every restaurant will try to provide maximum services for its guests. The strength of this business is how the owners of the restaurants offer the best services to their guests in order to satisfy their needs. Each restaurant will try to add different values for products ad services as well as services provided to the guests. These added values create differentiation from one to another restaurant.

The customers' selection towards a restaurant causes the emergence of competition in the culinary business. Not all restaurants succeed in competing and dominating the market according to the set targets. For this reason, precise marketing policy and strategy are needed to deal with increasingly incisive competition. In the midst of competition, the task and role of the marketing department are to strive in order to increase the sales volume from time to time. Marketing is the spearhead in the business world.

These marketing strategies are tips for marketing the products properly to achieve the desired level of profits. All kinds of strategies need to be developed by every marketing employee. The aim is to be able to compete in every situation and if the marketing strategies adopted by the restaurant be able to run smoothly, it will increase the sales.

The concept of marketing said that the key to achieving the goal of the restaurant consist of needs of determination and market segment desire as well as delivering satisfaction expected to be effective and efficient in comparison with the competitor.

The aims of this research are:

1. To understand the strengths and weaknesses of Bu Hartin Kulon Progo's restaurant.

2. To discover the opportunity and the threat of $\mathrm{Bu}$ Hartin Kulon Progo's restaurant.

3. To know the marketing mix at Bu Hartin Kulon Progo's restaurant.

4. To cognize the competitive strategy of Bu Hartin Kulon Progo's restaurant.

\section{Research Benefit}

The theoretical benefit of this research is to increase knowledge about the 
T. Prasetyo Hadi Atmoko and Heni Widyaningsih: Analysis of Bu Hartin Restaurant Competitive Strategy in the Development of Culinary in Wates Kulon Progo"

development of culinary tourism. While the practical benefit is as the competitive strategy guidelines on restaurants for business.

\section{LITERATURE REVIEW Strategy}

Strategy is the overall concept of how a company organizes all activities itself in order to obtain the aim of the business running successfully, competing, and making result of returns (Charles, 2010). Meanwhile according to Rangkuti (2016:3) strategy is an effort to achieve goals, the success of a strategy is largely determined by changes in the environment, competitors, and organizational situations, and the factors in formulating the strategy. Overviewed from management, strategic management is the art and science of formulating, implementing, and evaluating cross-functional decisions that make it possible to achieve goals. According to Pearce and Robinson (2014), strategic management is a series of decisions and actions that result in the formulation and implementation of plans o achieve goals.

The strategic management focuses on integrating management, marketing, finance/accounting, products/operations, research and development, computer information system to attain organizational goals with competitive advantage providing its own characteristics that differentiate it from other businesses (Riswandi, 2016).

\section{Promotion}

In order to prospective tourists acquire complete and accurate information about the products or services to be offered for sale, there needs to have promotional materials such as brochures, leaflets, booklets, posters or tourist maps. Therefore, through the source of information, they can organize travel tours well and satisfactorily. The success of marketing depends on two factors, such as:

1. Factor that can be controlled
Promotion can be changed with a variety of strategies such as restaurants that are able to change or replace the promotional media used to advertise their products.

2. Factor cannot be controlled

Factors that cannot be controlled are out of reach events, called external factors, i.e. competition, regulation and legalization, economic environment, technology, as well as social and cultural environment.

\section{Marketing Mix}

The success of a company in achieving its intended purpose depends on the company's strategy itself. One of the tools used to develop a marketing strategy is to exert the marketing mix. The service marketing mix is marketing tools that consist of seven elements, i.e. products (service), price, place, promotion, participants, physical evidence, and process. Inside organizations reached the competitive advantage. The organizations engaged in services use the service marketing mix to formulate their strategies for achieving high customer value that finally determine the competitive position in their target markets. According to Kotler (2009), the marketing mix such as:

\section{Product (service)}

Product produced by producers aimed to fulfill the needs of guests with the expectation that the guests feel satisfied with what they buy. Products are generated through a long process starting from procurement of materials, selection to the final output to be readily distributed to the guests. One of the service characteristics is intangible and can not be changed ownership. In actual service products, consumers do not buy goods or services but obtaining the benefit and value of something offered. What it is offered shows a number of advantages that can be perceived by consumers from a purchase of service products.

\section{Price}


T. Prasetyo Hadi Atmoko and Heni Widyaningsih: Analysis of Bu Hartin Restaurant Competitive Strategy in the Development of Culinary in Wates Kulon Progo"

The term price actually applies to companies whose output is tangible goods, while services are better known as tariffs. Nonetheless, literary has the same understanding. Every effort needs to run its operations in order to always getting the profit indubitably. Price is the amount of value exchanged to obtain a product. Low price leads to the perception of non-quality products, on the contrary, the high price raises to the perception of the quality product. Meanwhile, if the price is higher, the consumers will also be reluctant to buy.

\section{Location}

The strategic location of the restaurant will be one of the strengths that will give the benefits because the strategic location of the restaurant will be easy to reach.

\section{Promotion}

The guests choose and use goods or services because first they know what they need in this case the restaurant must be very clever to convey what they offer to guests. The process of communication between the restaurant and guests considered a promotion. Promotion is one of the determinants of the success of a marketing program, regardless of the high quality of a product. If the consumers have never heard of it and are not sure that the product will be worthwhile, they will never buy it. Promotion is a form of marketing communication which is a marketing activity as an effort to spread information, influence/persuade the target market for the company and its products till willingly to accept and buy as well as be loyal to the product offered. Promotion is basically a process of introducing, notifying and reminding products and services produced by service providers to potential consumers and even regular consumers so that they have the intention to have the product and service through the purchasing process.

\section{Participant}

The success in attracting customers from service providers is determined by the expertise of officers in serving guests who want to enjoy the service offered, therefore the service has one of the intangible features that are obligation to the employee to convince the customers who apply the services.

Many things can influence customers' decisions in the service industry. For example, it reflects to the proper employee behavior in the way of speaking, wearing clothes and serving customers.

\section{Physical Evidence}

One of its services is tangible, therefore other than people those who can affect purchasing decisions are physical facilities. Cause in service, the customers who come to the restaurants mostly want to enjoy something while relaxing, therefore it is necessary to pay attention to the elements to support the physical facilities. The elements are included in the physical environment, physical buildings, equipment, appliance, and other items that are combined with the services.

\section{METHOD}

The research is descriptive using a field research approach that the research is directly to $\mathrm{Bu}$ Hartin Restaurant with aiming to know the competitive strategy. Data collection techniques are conducted by:

1. Literature research, i.e. data collection is collected by exploring sources of information from the experts to support this research theory

2. The interview was conducted with the owner of $\mathrm{Bu}$ Hartin restaurant and regular customers.

3. Questionnaires that have been distributed to obtain an assessment of the statements that have been submitted to the resource persons.

4. Documentation with data collection techniques through drawings, photos in accordance with the research.

In this study, data were analyzed using SWOT analysis. According to Utama (2012) SWOT analysis is an analysis tool that is generally used to formulate strategies for the identification of various factors 
T. Prasetyo Hadi Atmoko and Heni Widyaningsih: Analysis of Bu Hartin Restaurant Competitive Strategy in the Development of Culinary in Wates Kulon Progo"

strategically based on intuition (comprehension and knowledge) towards objects. The steps for formulating alternative strategies through the SWOT matrix are as follow:

1. Put a list of weaknesses, strengths, opportunities, and threats in each cell in the SWOT matrix.

2. Interpret the combination of strengths and opportunities then recording the results in the SO strategy cell ( Strengths Opportunities)

3. Interpret and combine weaknesses and opportunities then recording the result in the WO (Weaknesses Opportunities) strategy cell.

4. Interpret and combine strengths and threats then recording the results in the ST (Strengths Threats) strategy cell.

5. Interpret and combine weaknesses and threats then recording the results in the WT (Weaknesses Threats) strategy cell.

Table 1: SWOT Analysis

\begin{tabular}{|c|c|c|}
\hline IFAS & $\begin{array}{l}\text { Strength (S) } \\
\text { Determine the } \\
\text { Internal } \\
\text { Strength } \\
\text { factors }\end{array}$ & $\begin{array}{l}\text { Weaknesses }( \\
\text { W) } \\
\text { Determine the } \\
\text { Internal } \\
\text { Weakness } \\
\text { factors }\end{array}$ \\
\hline $\begin{array}{l}\text { Opportunities } \\
\text { (O) } \\
\text { Determine } \\
\text { External } \\
\text { Opportunity } \\
\text { factors }\end{array}$ & $\begin{array}{l}\text { SO Strategy } \\
\text { Create } \\
\text { strategies that } \\
\text { use power to } \\
\text { take advantage } \\
\text { of } \\
\text { opportunities }\end{array}$ & $\begin{array}{l}\text { WO Strategy: } \\
\text { Create } \\
\text { strategies that } \\
\text { minimize } \\
\text { weaknesses to } \\
\text { take advantage } \\
\text { of } \\
\text { opportunities }\end{array}$ \\
\hline $\begin{array}{l}\text { Threats }(\mathrm{T}) \\
\text { Determine } \\
\text { External } \\
\text { Threats factors }\end{array}$ & $\begin{array}{l}\text { ST Strategy: } \\
\text { Create } \\
\text { strategies that } \\
\text { use power to } \\
\text { overcome } \\
\text { threats }\end{array}$ & $\begin{array}{l}\text { WT Strategy: } \\
\text { Create } \\
\text { strategies that } \\
\text { minimize } \\
\text { weaknesses } \\
\text { and avoid } \\
\text { threats }\end{array}$ \\
\hline
\end{tabular}

Source: Rangkuti (2016)

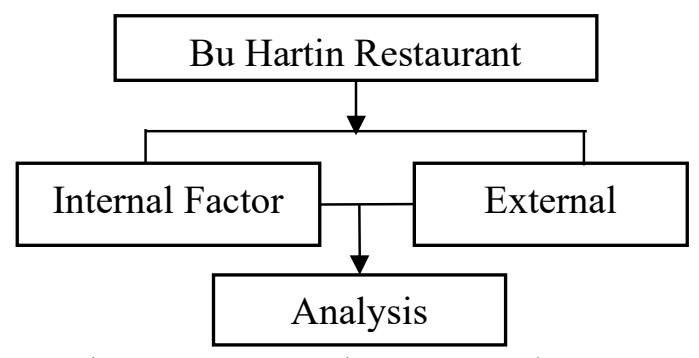

Figure 1: Research Framework

In strategy analysis, the SO (Strengths Opportunities) Strategy is made based on the mindset of the object that is by utilizing all the power to seize and take advantage of as many opportunities as possible. The ST (Strengths Threats) Strategy uses the power of the object to overcome the threats The WO (Weaknesses Opportunites) strategy is implemented based on the utilization of existing opportunities by minimizing existing weaknesses. WT (Weaknesses Threats) Strategy is based on activities that are defensive and try to minimize existing weaknesses and avoid threats. Framework of mind in formulating strategies in the SWOT analysis can be seen in figure 1 .

\section{RESULT AND DISCUSSION}

$\mathrm{Bu}$ Hartin restaurant is located at Gunung Gempal Jalan Raya Wates Kulon Progo. Based on the analysis, internal and external factors of $\mathrm{Bu}$ Hartin restaurant are as follows:

A. Strengths and Weaknesses

1. Strengths

Strengths of Bu Hartin restaurant are:

a. Has a special menu of free-range chicken, ribs soup, grilled ribs.

b. Strategic location placed on the provincial highway, close to offices, 15 minutes from YIA airport.

c. It only takes 5 minutes to downtown.

d. Beautiful atmosphere with Joglo nuanced structure.

e. Has an office market segment, students, and the general public

f. Prompt serving time, approximately 10 minutes. 
T. Prasetyo Hadi Atmoko and Heni Widyaningsih: Analysis of Bu Hartin Restaurant Competitive Strategy in the Development of Culinary in Wates Kulon Progo"

g. Have employees who are experts in their fields.

h. Facilitate a Mushola (a prayer room), toilet, and Gazebo for resting.

2. Weaknesses

$\mathrm{Bu}$ Hartin restaurant has the weaknesses of a tight parking lot too close to a highway.

B. Opportunities and Threat

1. Opportunites

The opportunities of Bu Hartin restaurant are:

a. Raw materials are easily obtainable in traditional markets

b. Often used for gathering and office meeting

c. YIA airport creates business opportunities increasingly widespread.

2. Threat

The number of competitors popped up mainly for catering.

C. Marketing Mix

The marketing mix of $\mathrm{Bu}$ Hartin restaurant includes seven elements, which are:

1. Product (Service)

$\mathrm{Bu}$ Hartin restaurant produces special menu products that are freerange chicken, ribs soup, and grilled ribs.

2. Price

The food price of $\mathrm{Bu}$ Hartin restaurant is an affordable for students as well as office clerks.

3. Place (Location)

The location of $\mathrm{Bu}$ Hartin restaurant which is very strategic close to the city center and placed on a provincial road will be one of the strengths that give benefit for $\mathrm{Bu}$ Hartin restaurant and even for regular custome because of the strategic location and easily accessed.

\section{Promotion}

$\mathrm{Bu}$ Hartin restaurant's promotion through social media.

5. Participant

$\mathrm{Bu}$ Hartin restaurant has wellexperienced employees in their fields so that they serve to the customers well.

6. Physical evidence

One of the services is intangible. Not only people but also other option physical facilities can influence the purchasing decision of customers. Physical facilities owned by BU Hartin restaurant are Gazebo used as a place for the visitors rest area.

\section{Process}

The cooking process at $\mathrm{Bu}$ Hartin restaurant uses special and delicious spices so that it is suitable in all circles, the cooking process is quite fast approximately 10 minutes so that the customers do not need to wait a long time.

\section{Competitive Strategy}

The restaurant business will be eminent if it has more values than its competitors. Competitive advantage will render more profits and the restaurant will survive a long time compared to its competitors.

The following table is Strengths, Weaknesses, Opportunities, and Threats of $\mathrm{Bu}$ Hartin restaurant, which are summarized in the IFAS and EFAS table matrix as follows:

Table 2: IFAS Matrix's Bu Hartin Restaurant

\begin{tabular}{llll}
\hline $\begin{array}{l}\text { Indicators of internal } \\
\text { strategies }\end{array}$ & Weight & Rating & Score \\
\hline $\begin{array}{l}\text { Strength (S) } \\
\text { 1. The menu presented }\end{array}$ & 0,14 & 2 & 0,28 \\
a more diverse and & 0,12 & 2 & 0,24 \\
\hline
\end{tabular}


T. Prasetyo Hadi Atmoko and Heni Widyaningsih: Analysis of Bu Hartin Restaurant Competitive Strategy in the Development of Culinary in Wates Kulon Progo"

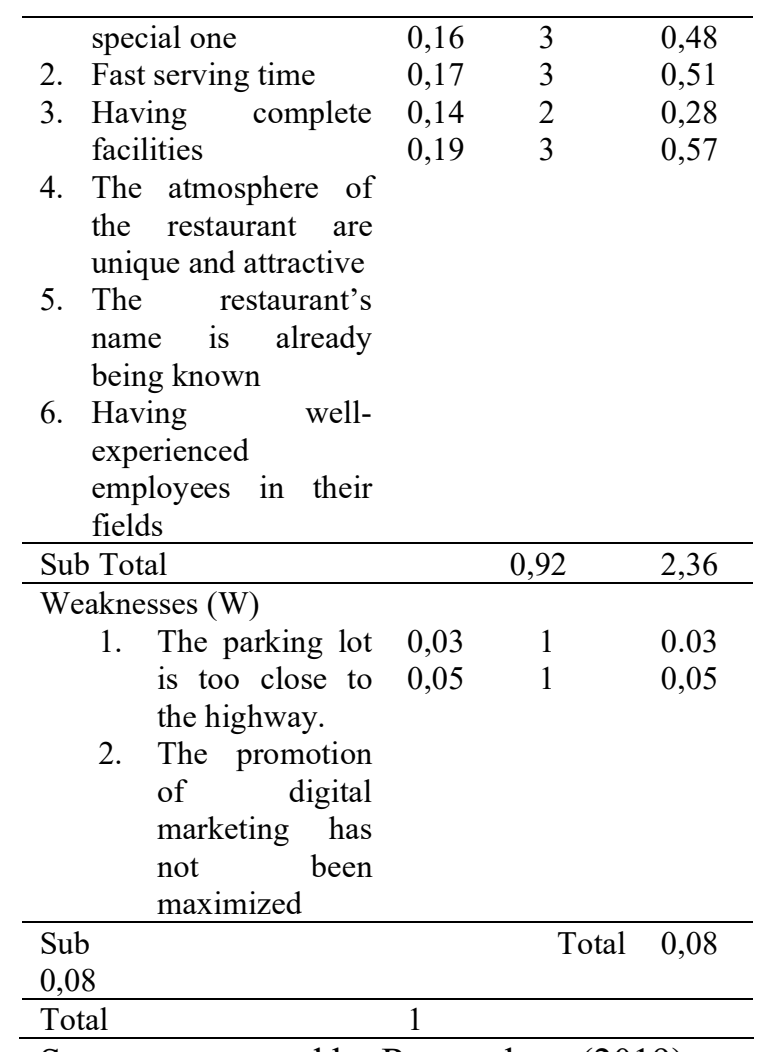

Source: processed by Researchers (2019)

Table 3: EFAS Matrix's Bu Hartin Restaurant

\begin{tabular}{|c|c|c|c|}
\hline $\begin{array}{l}\text { Indicators of internal } \\
\text { strategies }\end{array}$ & Weight & Rating & Score \\
\hline \multicolumn{4}{|l|}{ Opportunities $(\mathrm{O})$} \\
\hline 1. The construction & 0,18 & 3 & 0,54 \\
\hline building of YIA & 0,14 & 3 & 0,42 \\
\hline airport increase & 0,12 & 3 & 0,36 \\
\hline regular customers & 0,12 & 3 & 0,36 \\
\hline $\begin{array}{l}\text { 2. Located in the } \\
\text { province and office }\end{array}$ & 0,20 & 4 & 0,80 \\
\hline lane & 0,17 & 3 & 0,51 \\
\hline $\begin{array}{l}\text { 3. Often used for office } \\
\text { events }\end{array}$ & & & \\
\hline $\begin{array}{l}\text { 4. Raw ingredient } \\
\text { convenient to be } \\
\text { obtained in } \\
\text { traditional market }\end{array}$ & & & \\
\hline $\begin{array}{l}\text { 5. The establishment of } \\
\text { PHRI branch fo } \\
\text { Yogyakarta become } \\
\text { a business container } \\
\text { of Kulon Progo } \\
\text { restaurants }\end{array}$ & & & \\
\hline $\begin{array}{l}\text { 6. The existence of a } \\
\text { training program } \\
\text { from related agency } \\
\text { to improve tourism } \\
\text { HR in Kulon Progo }\end{array}$ & & & \\
\hline
\end{tabular}

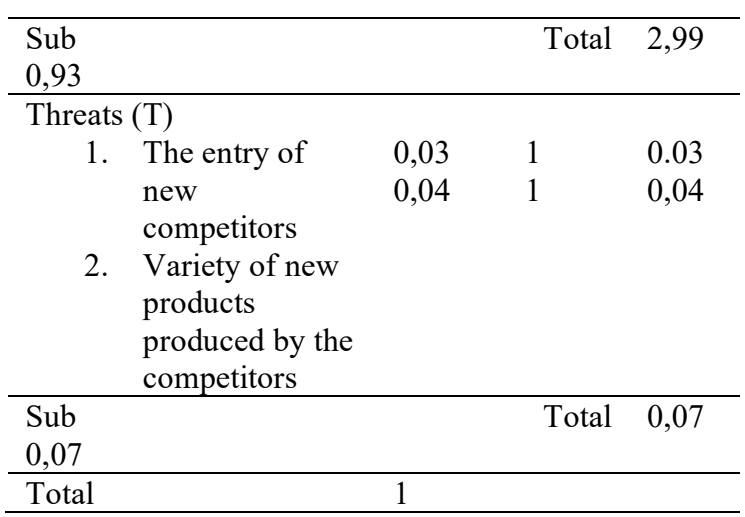

IFAS table analysis presents that the strength indicator has a total score of 2.36 and weaknesses has a total score of 0.08 . Whereas the EFAS table analysis shows that the opportunity indicator score value is 2.99 and the threat indicator is 0.07 . From this analysis, it discovers the strengths' value above the weaknesses and opportunities values above the threat value so that $\mathrm{Bu}$ Hartin restaurant has the opportunity to maximize the strengths of the competition. Based on IFAS and EFAS Matrix analysis could compile SWOT matrix to formulate SO, WO, ST and WT strategies, as follows:

Table 4: SWOT Bu Hartin Restaurant

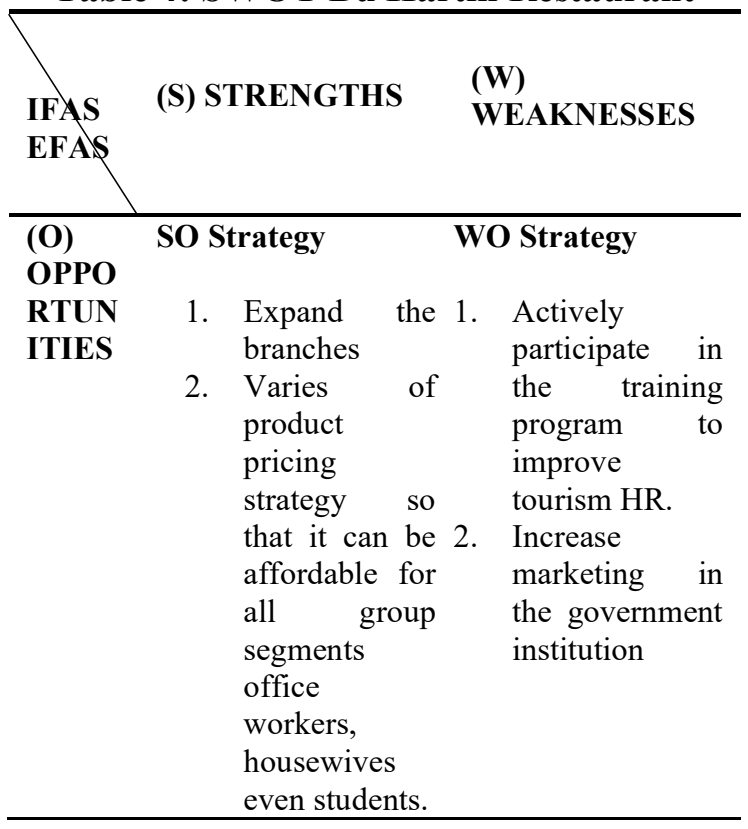


T. Prasetyo Hadi Atmoko and Heni Widyaningsih: Analysis of Bu Hartin Restaurant Competitive Strategy in the Development of Culinary in Wates Kulon Progo"

\begin{tabular}{|c|c|c|}
\hline (T) & ST Strategy & WT Strategy \\
\hline $\begin{array}{l}\text { THRE } \\
\text { ATS }\end{array}$ & $\begin{array}{l}\text { 1. Maintain } \\
\text { the } \\
\text { uniqueness } \\
\text { of the } \\
\text { restaurant } \\
\text { as its } \\
\text { special } \\
\text { characteristi } \\
\text { c } \\
\text { 2. Increase } \\
\text { preferred } \\
\text { products in } \\
\text { various } \\
\text { segments, } \\
\text { housewives, } \\
\text { students, } \\
\text { employees, } \\
\text { and offices. }\end{array}$ & $\begin{array}{l}\text { 1. Marketing in } \\
\text { various sectors } \\
\text { and placing } \\
\text { advertisements } \\
\text { on many social } \\
\text { media such as } \\
\text { Facebook, } \\
\text { Instragram, and } \\
\text { WhatsApp to } \\
\text { attract loyal } \\
\text { customers. } \\
\text { 2. Expand the } \\
\text { parking lot }\end{array}$ \\
\hline
\end{tabular}

Regarding the SWOT matrix image, the result of the analysis are mapped to the strengths and opportunities, a strategy recommendation is to expand branches and add food products with various prices so that it is affordable for all segments of offices, housewives, and students.

\section{CONCLUSIONS}

According to the discussion that has been described, the following conclusions can be drawn: Based on the SWOT analysis, the strength factor of $\mathrm{Bu}$ Hartin restaurant has a score of 2.36 and a weakness factor of 0.08 . The opportunity factor has a score of 2.99 and the threat has a score of 0.07. Marketing mix of Bu Hartin restaurant consists of seven elements, i.e. product, price, place, promotion, participants, physical evidence, and process. The products of $\mathrm{Bu}$ Hartin restaurant produced special menus: free-range chicken, grilled ribs and ribs soup. The food at $\mathrm{Bu}$ Hartin restaurant is an affordable price for students and even office workers. The location of $\mathrm{Bu}$ Hartin restaurant is a very strategic place close to the city center. The promotion of $\mathrm{Bu}$ Hartin restaurant is conducted through social media. The employees of $\mathrm{Bu}$ Hartin restaurant are wellexperienced in their fields so that their services are so good for customers. Physical facilities of $\mathrm{Bu}$ Hartin restaurant such as Gazebo can be used as a resting place for customers. The cooking process of $\mathrm{Bu}$ Hartin restaurant use special and delicious spices so that it is suitable for all circles, the cooking process is quite fast, approximately 10 minutes so that the customers do not wait a long time for the cooking process.

Based on the SWOT matrix, Bu Hartin restaurant is on a SO strategy by increasing promotion through social media and expanding branches. This research recommends following itmes, such as increasing promotions activity for the restaurants by creating a website and Google business and creating a promo menu package.

\section{REFERENCES}

Atmoko, Prasetyo Hadi. (2018). Strategi Pemasaran untuk meningkatkan Volume Penjualan di Cavinton Hotel Yogyakarta. Journal Of Indonesian Tourism, Hospitality and recreation. Vol 1, No 2, hal 83-96.

Charles E, Bamfor. 2010. Strategy: Sustainable Advance and Performance. Canada: South Western Cengage Learning.

Pearce, John A, and Richard B Robinson. (2014). Manajemen Strategis Formulasi Implementasi dan Pengendalian. Jakarta: Salemba Empat.

Rangkuti, Freddy. (2016). Teknik Membedah Kasus Bisnis. Jakarta: PT: Gramedia Pustaka Utama.

Palupi, Retno, dan Rosita (2018). Analisis Komparasi Persepsi Atribut Kualitas Restoran Antara Pelanggan yang puas dengan Pelanggan Yang Kurang Puas di Restoran Jepang All You Can Eat. Journal of Indonesian Tourism, Hospitality And Recreation, Vol 1, No 2, hal 31-40.

Riswandi, Akbar. (2016). Analisis Strategi Bersaing Rumah Makan (Studi Pada 
T. Prasetyo Hadi Atmoko and Heni Widyaningsih: Analysis of Bu Hartin Restaurant Competitive Strategy in the Development of Culinary in Wates Kulon Progo"

Rumah Makan Darisa Café Campus). Jurnal Ilmu Manajemen Universitas Tadulako. Vol 2, No 3, hal 293-304.

Atmoko, Prasetyo dan Heni widyaningsih. (2018). Manajemen dan Bisnis Perhotelan. Yogyakarta: Explore.tama, Rai. (2012). Metodologi penelitian Pariwisata dan Perhotelan. Yogyakarta: Andi.

Kotler, Philip dan Keller, Kevin Lane. (2009). Marketing Management. Penerjemah Bob Sabran. Jakarta: Erlangga. 